\title{
PERANAN SPIRITUAL DALAM RAWATAN PALIATIF
}

THE ROLE OF SPIRITUALITY IN PALLIATIVE CARE

Hasimah Chik*, Che Zarrina Sa'ari**, Loh Ee Chin ${ }^{\#}$

${ }^{* *}$ Department of `Aqidah \& Islamic Thought. Academy of

Islamic Studies. University of Malaya. 50603. Kuala Lumpur. Malaysia.

\#Department of Medicine, Faculty of Medicine, University

of Malaya. 50603. Kuala Lumpur. Malaysia.

Email: **zarrina@um.edu.my

\begin{abstract}
Khulasah
Spiritualiti merupakan satu elemen di dalam penjagaan paliatif di samping elemen fizikal, mental dan sosial. Setiap elemen dalam penjagaan paliatif mempunyai peranan dan kepentingan yang diperlukan dalam meningkatkan kualiti penjagaan. Spiritualiti boleh memberi impak yang besar dalam kehidupan seseorang. Tujuan penulisan yang memanfaatkan kaedah analisis kandungan melalui kajian kepustakaan ini adalah untuk membincangkan dengan lebih mendalam tema-tema spiritual dan kepentingannya dalam penjagaan paliatif. Kajian ini mendapati usaha untuk mencapai impak maksima dalam rawatan memerlukan kerjasama pesakit, ahli keluarga, rakan dan juga pengamal perubatan. Spiritualiti diyakini boleh memberi sumbangan yang besar kepada peningkatan kualiti hidup, kerana kekurangan dalam aspek spiritual boleh mendatangkan pelbagai masalah dan kesusahan. Elemen psikoterapi merupakan alternatif untuk membantu dalam penekanan aspek spiritualiti terhadap pesakit.
\end{abstract}

Kata kunci: spiritual; paliatif; psikososial; fizikal; emosi.

\section{Abstract}

Spirituality is an element in palliative care in addition to physical, mental and social elements. Every element 
in palliative care has the roles and interests necessary to improve the quality of care. Spirituality can have a great impact on one's life. The purpose of article that utilized content analysis method through literature study is to discuss in-depth spiritual themes and their importance in palliative care. The study finds the effort to achieve maximum impact in the treatment of patients requires the cooperation of patients, family members, friends and medical practitioners. Spirituality is believed to be of great contribution to the improvement of the quality of life, as spiritual inferiority can bring many problems and distresses. The psychotherapy element is an alternative to helping in emphasizing the aspect of spirituality towards the patients.

Keywords: spiritual; palliative; psychosocial; physical; emotional.

\section{Pendahuluan}

Kajian pada hari ini semakin banyak dijalankan bagi menambahbaik penjagaan paliatif. Secara umumnya penjagaan paliatif adalah suatu yang memberi kesan positif kepada pesakit dan ahli keluarga sama ada daripada aspek kehidupan dan lain-lain. Penjagaan paliatif adalah penjagaan khusus kepada pesakit yang tiada harapan untuk hidup atau pesakit yang menghadapi penyakit yang kritikal di ambang kematian. Rawatan ini adalah suatu rawatan holistik yang terdiri daripada interdisiplin kepakaran dalam usaha memberi yang terbaik kepada para pesakit yang mengalami penyakit berisiko. Rawatan ini bukanlah menjanjikan kesembuhan secara total, akan tetapi berusaha untuk memberi kesan positif dalam diri pesakit sama ada dari segi fizikal, spiritual, sosial, emosi dan psikologi.

Penjagaan paliatif akan memainkan peranan sehingga pesakit dan ahli keluarga dapat menjalani kehidupan yang lebih baik. Sekiranya pesakit telah sampai ke akhir hayatnya dan keluarga diuji dengan kematian, penjagaan paliatif akan beralih fokus kepada ahli keluarga bagi 
meneruskan sokongan membantu fasa perkabungan. Sesi ini akan selesai setelah keluarga dan orang sekeliling pulih sepenuhnya, iaitu boleh menerima dengan hati yang redha dan boleh meneruskan kehidupan mendatang.

Dr Ednin Hamzah, Pengarah Hospis Malaysia menyatakan bahawa penjagaan paliatif atau juga dikenali sebagai penjagaan hospis menjadi lebih relevan dan penting untuk dijalankan kerana kelemahan hospital yang menjalankan aspek rawatan berdasarkan rawatan kuratif semata-mata. ${ }^{1}$ Rawatan penjagaan paliatif akan diberikan sejurus selepas didiagnos seseorang individu itu menghidapi penyakit yang berisiko tinggi dan peluang tipis untuk sembuh sepenuhnya. Dalam situasi penjagaan ini, rawatan akan diberikan tanpa membezakan agama, budaya, bangsa, etnik dan pegangan pesakit. ${ }^{2}$

Namun, setiap rawatan yang diberikan akan mengikut perancangan dan garis panduan yang bersesuaian dengan latar belakang pesakit terutamanya aspek keagamaan, budaya dan pegangan. Setiap elemen tersebut dihormati dan diberi keutamaan berdasarkan permintaan dan kehendak pesakit serta ahli keluarga pesakit. Menjadi satu kayu ukur kejayaan rawatan adalah apabila pesakit dan ahli keluarga dapat menjalani kehidupan dengan lebih positif dan berkualiti.

Kajian di Barat oleh Christina Faull mendapati bahawa penjagaan paliatif adalah penjagaan terhadap pesakit dan keluarga pesakit secara aktif oleh kumpulan multiprofesional apabila pesakit tidak lagi mampu memberi

${ }^{1}$ E. Hamzah, "Palliative Care in the Community," (Kertas Kerja, The International Conference on Health Sciences, Sunway Pyramid Convention Centre, Subang Jaya, 2005).

2 C. Puchalski, B. Ferrell \& R. Virani, "Improving the Quality of Spiritual Care as a Dimension of Palliative Care: The Report of the Consensus Conference," Journal of Palliative Medicine, 12(10) (2009), 885. 
tindakbalas pada rawatan perubatan klinikal. ${ }^{3}$ Marieke Groot mengatakan bahawa penjagaan paliatif merupakan aspek penting dalam penjagaan umum juga, yang mana fasa asas paliatif adalah hubungan yang rapat antara pesakit dan ahli keluarga. ${ }^{4}$ Manakala Peter mengatakan pesakit yang melalui rawatan ini mampu hidup lebih lama. ${ }^{5}$ William pula berpendapat penjagaan paliatif yang baik ialah apabila pesakit dapat mati dalam keadaan yang dikehendaki oleh pesakit dan keluarga pesakit, seperti mati di rumah dan di sisi ahli keluarga yang lain. ${ }^{6}$ Pendapat beliau ini disokong oleh Claudia Virdun. ${ }^{7}$

Manakala pendokong paliatif yang terdiri daripada sarjana Islam seperti Ednin Hamzah, menyatakan bahawa penjagaan paliatif tersebut mampu menjana perasaan kelegaan kepada pesakit, ${ }^{8}$ yang mana ianya disokong oleh Maliana yang berpendapat paliatif menyumbang kepada kualiti hidup dan menjadikan hidup pesakit semakin

${ }^{3}$ C. Faull, Y. Carter, \& R. Woof, Handbook of Palliative Care (United Kingdom: Blackwell Science, 1998), 3.

${ }^{4}$ M. M. Groot, M. J. Vernooij-Dassen, B. J. Crul, \& R. P. Grol, “General Practitioners (Gps) and Palliative Care: Perceived Tasks and Barriers in Daily Practice," Palliative Medicine 19(2) (2005), 113.

${ }^{5}$ Peter J Franks, C. Salisbury., Nick Bosanquet et al. "The Level of Need for Palliative Care: A Systemtic Review of the Literature," Palliative Medicine, 14, (2000), 97.

6 W. Breitbart, "The Goals of Palliative Care: Beyond Symptom Control," Palliative \& Supportive Care, 4(01) (2006), 1-2. doi:10.1017/S1478951506060019, 1

${ }^{7}$ C. Virdun, T. Luckett, \& P. M. Davidson, "Dying in the Hospital Setting: A Systematic Review of Quantitative Studies Identifying the Elements of End-Of-Life Care That Patients and Their Families Rank As Being Most Important," Palliative Medicine, 29(9) (2015), 774 796.

${ }^{8}$ R. Dain, "Penjagaan Paliatif beri Kelegaan Pesakit," Utusan Online. (2011, 27 October). Diakses 2 Disember 2014 daripada http://ww1.utusan.com.my/utusan/info.asp?y=2011\&dt=1027\&pub= Utusan_Malaysia\&sec=Kesihatan\&pg=kn_01.htm 
bermakna di akhir usianya. ${ }^{9}$ Apabila ditimpa penyakit, Islam menganjurkan umatnya untuk mencari penawar berdasarkan hadis Nabi SAW yang bermaksud, "Tidak ada sebarang penyakit yang Allah datangkan, kecuali dengannya ada penawar". ${ }^{10}$ Penawar itu dimaksudkan dengan berusaha mengawal dan menyembuhkan penyakit tersebut. Justeru, penjagaan terhadap orang sakit adalah suatu penawar yang merupakan suatu akhlak mulia dan dipuji di sisi Islam. ${ }^{11}$

Mohamad Zafir menekankan dalam Islam, persoalan hidup dan mati adalah milik Tuhan Pencipta, dan pengamal perubatan tidak dapat menjangkakan secara tepat tempoh masa yang masih tinggal bagi seseorang pesakit. Namun, sebagai seorang perawat yang berdepan dengan pelbagai pengalaman dan kajian yang dijalankan, boleh meletakkan anggaran kasar tahap kritikal seseorang pesakit bagi memberi gambaran kepada ahli keluarga agar bersedia dengan apa yang bakal berlaku. ${ }^{12}$ Sebagai umat manusia, kehidupan dan kematian adalah suatu perjalanan yang perlu ditempuhi oleh setiap individu. Justeru, Islam menerapkan kefahaman bahawa ujian kesakitan adalah dianggap suatu kafarah atau penghapus dosa dan kesilapan lalu. ${ }^{13}$

Terdapat garis panduan asas ${ }^{14}$ dalam Islam mengenai isu perubatan iaitu tidak boleh mendatangkan mudarat kepada pesakit (nonmaleficence), keadilan dan

9 M. S. Mahajudin, "Peran Psikogeriatri \& Perawatan Paliatif dalam Upaya Meningkatkan Kesehatan Para Lanjut Usia," Anima, Indonesian Psychological Journal, 23(3) (2008), 287.

${ }^{10}$ Hadis riwayat al-Bukhārī, Mukhtașār Sahīh al-Imām al-Bukhārī, Bāb Kitāb al-Ṭibb, no. hadis 2225. Rujuk N. Taheri, "Health Care in Islamic History and Experience," EthnoMed (2008). Diakses pada 12 November 2014, http://ethnomed.org/cross-culturalhealth/religion/health-care-in-islamic-history-and-experience/

${ }^{11}$ M. Z. Al-Shahri \& A. Al-Khenaizan, "Palliative Care for Muslim Patients," The Journal of Supportive Oncology, 3(6) (2005), 433.

12 Ibid..

${ }^{13}$ Ibid, 432.

${ }^{14}$ Ibid, 433. 
kesamarataan bagi setiap orang bagi memenuhi hak setiap individu pesakit (justice), pesakit bebas membuat keputusan (autonomy), dan panduan yang terakhir ialah melakukan sesuatu yang mendatangkan faedah serta membuang sesuatu yang mendatangkan bahaya (beneficence). Oleh yang demikian, aspek penjagaan kesihatan dari sudut pandang maqūșid sharī ah adalah suatu yang bersifat darürat (keperluan penting). ${ }^{15}$

Secara kesimpulannya, penjagaan paliatif adalah suatu yang memberi manfaat dan sangat dituntut untuk dilaksanakan kerana dianjurkan oleh agama yang juga dibuktikan kepentingannya oleh kajian-kajian terdahulu. Namun, kaedah pelaksanaan terbaik kini masih lagi dalam kajian, dan pembaharuan demi pembaharuan ditemui dari pelbagai aspek penjagaan yang melibatkan fizikal, spiritual, sosial dan lain-lain.

\section{Spiritualiti Dalam Dimensi Penjagaan Paliatif}

Dalam perbincangan oleh Edwards et al., pesakit akan menerima lebih perhatian dalam aspek fizikal, peribadi dan kehidupan sosial daripada masyarakat sosial, namun apabila pesakit mula berada pada saat-saat akhir kehidupan, pesakit sendiri akan mula beralih fokus dan memerlukan perhatian dalam aspek spiritual. ${ }^{16}$ Kajian di Barat banyak menekankan aspek spiritual dalam penjagaan seperti kajian oleh Monod, Kellehear, Edwards dan lain-lain. Perkara ini menunjukkan antara elemen-elemen dalam penjagaan, elemen spiritual adalah elemen yang perlu diberi perhatian mendalam.

Maksud spiritual adalah berbeza berdasarkan pengalaman dan kehidupan seseorang. Spiritual secara

15 J. Auda, Maqasid Al-Shariah An Introductory Guide (Herndon: IIIT, 2008), 53.

16 A. Edwards, N. Pang, V. Shiu \& C. Chan, "The Understanding of Spirituality and the Potential Role of Spiritual Care in End-of-Life and Palliative Care: A Meta-study of Qualitative Research," Palliative Medicine, 24(8) (2010), 1. doi:10.1177/0269216310375860. 
umum adalah suatu fenomena atau keperluan asas seorang manusia yang membantu untuk mencipta makna dalam kehidupan. ${ }^{17}$

Spiritual dan keagamaan bagi sarjana Barat adalah sesuatu yang tidak sama berdasarkan apa yang digariskan oleh para sarjana seperti Monod, Kellehear dan lain-lain, akan tetapi kedua-dua perkara tersebut sangat berkaitan. Keagamaan adalah satu aspek perbincangan di bawah elemen-elemen spiritual. Linda Emanuel mengatakan bahawa spiritual pada fokus mereka adalah kepada pengalaman manusia itu sendiri, bukan mana-mana aspek ketuhanan atau keagamaan. ${ }^{18}$ Emanuel menggambarkan spiritual itu adalah sesuatu yang suci. Manakala Wright mengatakan spiritual adalah suatu yang bersifat bukan fizikal. ${ }^{19}$ Lepherd menyatakan spiritual merupakan satu bahagian yang penting dalam penjagaan orang sakit bagi mengekalkan kesejahteraannya kerana melibatkan keutuhan dalam seseorang individu..$^{20}$

Spiritual dalam huraian umum terdiri daripada empat elemen utama yang mempunyai perbincangan yang lebih terperinci. Empat elemen utama yang dibincangkan oleh Sefanie Monod dan Michael Wright dalam spiritualiti ialah makna kehidupan (meaning), pengalaman dalaman (transcendence), nilai (value) dan identiti psikososial (psychosocial identity). ${ }^{21} \quad$ Terdapat pelbagai lagi

${ }^{17}$ C. H. Sumner, "Recognizing and Responding," The American Journal of Nursing, 98(1) (1998), 29.

${ }^{18}$ L. Emanuel, G. Handzo \& G. Grant, "Workings of the Human Spirit in Palliative Care Situations: A Consensus Model from the Chaplaincy Research Consortium," Bmc Palliative Care, 14(13) (2015), 2. doi:10.1186/s12904-015-0005-3,

19 M. Wright, "Hospice Care and Models of Spirituality," European Journal of Palliative Care, 11(2) (2004), 75.

20 L. Lepherd, "Spirituality: Everyone has it, but what is it?" International Journal of Nursing Practice, 21(5) (2015), 567. doi:10.1111/ijn.12285.

${ }^{21}$ S. Monod, E. Rochat, C. Büla, \& B. Spencer, "The Spiritual Needs Model: Spirituality Assessment in the Geriatric Hospital Setting," 
perbincangan mengenai aspek spiritualiti yang mana setiap sarjana mengeluarkan elemen-elemen tersendiri berdasarkan kajian, observasi dan pengalaman masingmasing.

Makna kehidupan (meaning of life) ialah seseorang itu merasakan kehidupannya sangat bermakna dan mendapat semangat dan kekuatan dari dalam diri. Pesakit mempunyai tujuan dan matlamat utama dalam kehidupan, dan tidak terkesan dengan cabaran dan ujian yang melanda seperti sakit kritikal yang sedang dialami. Daripada aspek makna ini, pesakit akan dapat merasai keselesaan, keamanan juga ketenangan kerana terdapat sistem sokongan yang kuat daripada sekeliling. ${ }^{22}$ Kebiasaannya pesakit merasa disayangi dan dihargai. Antara sumber kekuatan ialah ahli keluarga, kawan, suasana alam, kesenian, muzik dan lainlain aspek dalam kehidupan. ${ }^{23}$ Perkara ini menunjukkan hubungan antara makna kehidupan dan faktor psikososial.

Transenden atau pengalaman dalaman atau satusatunya yang terbaik (transcendence) adalah aspek yang mana dipengaruhi oleh faktor luaran individu. Gowri dan Ellen menyatakan transenden merupakan suatu situasi rohani yang berpunca dari kuasa yang luar biasa. ${ }^{24}$ Peterman meletakkan transenden sebagai maksud utama spiritual, iaitu merasai kewujudan dan rasa keterhubungan. ${ }^{25}$ Wright menyokong kenyataan Gowri

Journal of Religion, Spirituality \& Aging, 22(4) (2010), 275 \& 276. doi:10.1080/15528030.2010.509987

${ }^{22}$ G. Anandarajah \& E. Hight, "Spirituality and Medical Practice: Using the HOPE Questions as a Practical Tool for Spiritual Assessment," American Family Physician, 63(1) (2001), 83.

${ }^{23}$ S. Caldeira, E. C. Carvalho \& M. Vieira, "Spiritual Distress-Proposing A New Definition and Defining Characteristics," International Journal of Nursing Knowledge, 24(2) (2013), 78.

${ }^{24}$ G. Anandarajah \& E. Hight, "Spirituality and Medical Practice," 84.

25 Amy H. Peterman et al. "Measuring Spiritual Well-Being in People with Cancer: The Functional Assessment of Chronic Illness TherapySpiritual Well-Being Scale (FACIT-Sp)," Annals of Behavioral Medicine, 24(1) (2002), 49. 
bahawa transenden adalah suatu keadaan dan tindakan melebihi keadaan biasa seseorang manusia. ${ }^{26}$ Aspek transenden mempengaruhi juga aspek makna dalam kehidupan.

Dimensi ketiga adalah nilai (value) yang membawa maksud sistem nilai yang menentukan kebaikan dan kebenaran bagi seseorang itu dalam melaksanakan segala tindakan dan pilihan yang perlu dilakukan dalam kehidupan. Sistem ini jarang disebut dalam aspek spiritual kerana ia merupakan manifestasi daripada aspek makna dan transenden. ${ }^{27}$ Michael Wright pula membincangkan nilai adalah suatu yang memberi maksud cinta, kebenaran, kemaafan dan perdamaian. ${ }^{28}$ Fegg membahagikan nilai kepada tiga teras iaitu kreativiti, pengalaman dan sikap. ${ }^{29}$

Elemen yang terakhir ialah identiti psikososial (psychosocial identity) yang dimaksudkan oleh Monod ialah persekitaran pesakit sebagai contoh masyarakat, penjaga pesakit, ahli keluarga dan orang terdekat yang boleh mempengaruhi identiti dan pendirian pesakit. ${ }^{30}$ Kebiasaannya pesakit mendapat sokongan kuat daripada hubungan yang baik dengan keluarga dan sekeliling. ${ }^{31}$ Golongan-golongan ini diperlukan pesakit agar pesakit merasakan dirinya disayangi, disentuh, sedia mendengar luahan, yang mengenalinya dan pesakit boleh rasa dirinya dimaafkan. Silvia dalam kajiannya terhadap pengertian dan

${ }^{26}$ M. Wright, "Hospice Care and Models of Spirituality," 77.

${ }^{27}$ S. Monod et. al., "The Spiritual Needs Model," 276.

${ }^{28}$ M. Wright, "Hospice Care and Models of Spirituality," 76.

29 M. Fegg, S. L'hoste \& M. Brandstatter, "Does the Working Environment Influence Health Care Professionals' Values, Meaning in Life and Religiousness? Palliative Care Units Compared with Maternity Wards," Journal of Pain and Symptom Management, 48(5), (2014), 916. doi:10.1016/j.jpainsymman.2014.01.009.

${ }^{30}$ S. Monod et. al., "The Spiritual Needs Model," 272.

31 L. R. Villagomeza, "Spiritual Distress in Adult Cancer Patients: Towards Conceptual Clarity," Holistic Nursing Practices, 19(6) (2005), 289. 
ciri-ciri keresahan spiritual meletakkan psikososial sebagai satu kayu ukur kepada keadaan spiritual yang baik. ${ }^{32}$

Manakala, membincangkan konsep pandangan Islam dalam menghuraikan aspek spiritual dalam kehidupan umumnya dan penjagaan kesihatan khususnya adalah menumpukan kepada asas penting dalam kepercayaan seseorang individu Muslim. Sebagai contoh Mohammad Zafir yang membincangkan penjagaan paliatif kepada pesakit Muslim, beliau mengetengahkan aspek spiritual sebagai komponen penting dan asas utama penjagaan paliatif. ${ }^{33}$ Hal ini kerana dalam diri seorang Muslim itu ada satu pegangan asas atau sistem kepercayaan. ${ }^{34}$ Dalam apa jua hal yang berlaku, seorang Muslim itu akan kembali kepada pegangan asas, iaitu keimanan dan kepercayaan kepada Allah yang menciptakan dan mengatur kehidupan hamba-Nya. Perbincangan dan pengkajian bagi sarjana Muslim adalah lebih kepada aspek spiritual yang berbentuk ritual agama, terapi seperti zikir, ibadah, bacaan al-Qur'an dan lain-lain.

Dalam Islam persoalan melambatkan atau mempercepatkan kematian tidak dibincangkan kerana ianya adalah urusan Tuhan yang menciptakan, dan ia adalah suatu yang pasti akan dihadapi oleh setiap insan. Sebaliknya perkara yang menjadi fokus kehidupan adalah suatu memberi manfaat agar kematian dihadapi dengan lebih tenang. Muslim lebih percaya kepada alam selepas kematian. ${ }^{35}$ Persoalan hidup dan mati adalah dalam kekuasaan Allah, manusia hanya mampu meramal atas apa yang berlaku, contohnya meletakkan tempoh masa pesakit mampu bertahan untuk hidup berdasarkan tahap kritikal seseorang pesakit dan kajian-kajian yang telah dijalankan.

${ }^{32}$ S. Caldeira et al., "Spiritual Distress-proposing a New Definition and Defining Characteristics," 78.

33 M. Z. Al-Shahri \& A. Al-Khenaizan, Palliative Care for Muslim Patients, 432.

${ }^{34}$ Ibid..

${ }^{35} \mathrm{~N}$. Taheri, Health Care in Islamic History and Experience, 3 
Membincangkan konsep perubatan dalam Islam ialah menggabungkan konteks fizik dan metafizik dalam rawatan. ${ }^{36}$ Konteks fizik yang dimaksudkan ialah konteks alamiah iaitu aspek kesihatan lahiriah pesakit, yang menggunakan sumber alam seperti bahan tradisional dalam perubatan dan metafizik ialah konteks Ilahiah atau spiritual yang menggunakan doa dan ayat-ayat ruqyah dalam perubatan. Ayat-ayat ruqyah adalah ayat-ayat yang baik daripada kitab Allah, al-Qur'an yang digunakan sebagai doa khusus dalam usaha penyembuhan. ${ }^{37}$

Pengertian dan konsep spiritual dalam Islam adalah sepakat, iaitu kembali kepada satu pegangan asas. Keagamaan dan spiritual adalah suatu yang tidak dapat dipisahkan dari segi makna dan hakikat kerana semua penjelasan akan kembali kepada konsep akidah bertuhankan Allah yang Esa. Perbezaannya hanya terletak pada bagaimana dan sedalam mana seseorang itu memahami dan meletakkan peranannya dalam kehidupan terutamanya apabila ditimpa sebarang ujian seperti sakit yang kritikal.

Dalam penjagaan pesakit kebiasaannya dipengaruhi oleh norma-norma setempat, yang mana norma mempunyai pengaruh kuat daripada budaya dan agama pada sesuatu tempat, ${ }^{38}$ contohnya di Arab Saudi sebagaimana yang dibincangkan oleh Mohamad Zafir, berkenaan adat-adat terhadap pesakit terutama kaum wanita dari segi pemakaian pesakit, juga sangat menolak aspek pergaulan lelaki dan

${ }^{36}$ M. Z. Marsuki \& M. B. Ibrahim, "Falsafah Perubatan Islam Menurut Jalal al-Din al-Suyuti Sebagai Muhaddis al-Asha irah," KUISAS, (2014), 3.

${ }^{37}$ H. Lukman, Latifah \& W. Nasyirudin, "Kesan Terapi Ruqyah dalam Merawat Pesakit HIVAIDS," Jurnal Al-Hikmah, 7(1) (2015), 121.

38 A. Padela, K. Gunter \& A. Killawi, Meeting the Healthcare Needs of American Muslims Challenges and Strategies for Healthcare Settings, (2011), 6 . 
perempuan walaupun ketika rawatan serta meletakkan aspek keTuhanan sebagai asas utama. ${ }^{39}$

Salasiah menyatakan spiritualiti merupakan keperluan bagi pesakit kerana ia boleh mempengaruhi keputusan yang dibuat oleh pesakit dan juga mempengaruhi kesihatan seseorang. ${ }^{40}$ Perkara ini juga disokong oleh Stefanie Monod yang mengatakan spiritual adalah dimensi yang penting dan sumber utama kepada pesakit dalam menghadapi kesakitan. Walaupun pemahaman yang berbeza oleh setiap individu terhadap konsep dan peranan spiritual, namun ada kesepakatan dalam meletakkan kepentingan spiritual. Pemahaman terhadap konsep spiritual adalah berdasarkan pengalaman, pegangan kepercayaan dan juga ilmu yang dimiliki.

Kajian daripada Moh Sholeh, ${ }^{41}$ Haslinda Lukman ${ }^{42}$ dan Muhammad Rifa' at ${ }^{43}$ membuktikan rawatan secara spiritual atau rohani mampu membantu penyembuhan secara keseluruhan. Membicarakan berkenaan penyakit kritikal, rawatan spiritualiti akan membantu mengurangkan kesakitan dan memberi kehidupan lebih baik di samping bantuan rawatan terhadap fizikal. Hal ini kerana fokus utama spiritual atau rawatan secara rohani adalah memperolehi ketenangan di akhir usia. Haslinda menerangkan sel kanser dalam tubuh akan lebih mudah mudah merebak sekiranya tiada ketenangan dalam diri seseorang pesakit. Moh Sholeh dalam kajian berkenaan 'Terapi Solat Tahajud' mampu merawat pelbagai penyakit.

39 M. Z. Al-Shahri, "Culturally Sensitive Caring for Saudi Patients," Journal of Transcultural Nursing, 13(2) (2002), 134.

${ }^{40}$ Ibid.

${ }^{41}$ M. Sholeh, Terapi Solat Tahajud: Menyembuhkan Berbagai Penyakit (Jakarta: Noura Books, 2012), 8

${ }^{42}$ H. Lukman, Latifah \& W. Nasyirudin, Kesan Terapi Ruqyah dalam merawat Pesakit HIVAIDS, 121.

${ }^{43}$ M. R. Razman \& S. H. Hamjah, "Dakwah dalam Dimensi Kerohanian Penjagaan Paliatif Menurut Pendekatan Badi' al-Zaman Sa'id alNursi," Jurnal Al-Hikmah, 7(1) (2015), 39. 
Beliau menerangkan bagaimana perjalanan hormonhormon dalam diri ketika tenang dan juga tertekan. Perkara ini menunjukkan perubahan emosi sangat mempengaruhi keadaan tubuh badan seseorang.

Berdasarkan perbincangan ilmuan Islam, Imam alGhazāli berkenaan konsep spiritual dalam kitabnya, Ihy $\bar{a}$ ' 'Ulüm al-Dín iaitu membawa empat elemen dalam spiritual iaitu qalb (jantung), ‘aql (akal), nafs (nafsu) dan rüh (roh) dan meletakkan qalb sebagai asas utama. ${ }^{44}$ Qalb membawa dua maksud iaitu sifat dalaman (inner nature) dan sifat semulajadi kedua (second nature). ${ }^{45}$ Inner nature mengandungi tiga sifat utama iaitu sifat dalaman manusia (haqīqah al-insān) yang mana bersifat sedar (mudrik), tahu ('ālim) dan ikut gerak hati ('ârif). Sifat-sifat ini amat berkait dengan hati fizikal. Al-Ghazāli meletakkan kedudukan dalaman hati ialah bersifat halus (lațiffah), kerohanian $(r \bar{u} h a n \bar{\imath})$ dan ketuhanan ( $r a b b \bar{a} n \bar{\imath})$, yang berkait rapat dengan tiga elemen penting yang selebihnya dalam spiritual iaitu rüh (rohani), nafs (jiwa) dan akal (`aql).

Roh (rūh) mempunyai dua pengertian, yang pertama ialah roh merupakan kuasa halus yang mengalir daripada fizikal hati masuk ke dalam seluruh badan manusia melalui perjalanan saraf manusia. Manakala pengertian kedua ialah satu kuasa halus (subtle faculty) ${ }^{46}$ yang berperanan untuk menyedari dan memahami sesuatu keadaan. Pengertian ini berkaitan dengan sifat semulajadi kedua qalb yang mana tidak dibincangkan secara mendalam oleh Imam al-Ghazāli kerana berdasarkan arahan Allah SWT kepada Rasulullah SAW dalam al-Qur'an dari surah al-Isra', ayat 85 yang bermaksud, "Dan mereka bertanya kepadamu tentang roh, katakan, "Roh itu dari perkara urusan Tuhanku, dan kamu

44 Al-Ghazālì, Ihyā' `Ulūm al-Dìn, jil. 3 (Damsyik: Maktabat `Abd alWakìl al-Darūbi, 1967), 4.

45 N. S. Mat Akhir, Al-Ghazali and His Theory of the Soul: A Comparative Study (Pulau Pinang: Penerbit Universiti Sains Malaysia, 2008), 175.

${ }^{46}$ Ibid., 176. 
tidak berikan ilmu pengetahuan melainkan sedikit sahaja ${ }^{47} . "$

Istilah kedua ialah jiwa (nafs) yang terbahagi kepada dua maksud utama iaitu yang pertama ialah nafs merupakan tempat nafsu kemarahan dan segala keinginan atau nafsu terhadap sesuatu. Para sufi mengatakan nafs adalah punca kepada segala sifat madhmūmah (negatif) dalam diri manusia ${ }^{48}$. Oleh itu manusia mestilah berusaha untuk melawan segala perkara negatif dalam diri dengan bersungguh-sungguh. Maksud kedua berhubungkait dengan sifat dalaman manusia yang terbahagi kepada tiga pembahagian utama iaitu al-nafs al-mutma'innah, al-nafs al-lawwāmah dan al-nafs al-ammārah bi al-sū'.

Al-nafs al-mutma'innah bermaksud keimanan tahap tertinggi, iaitu tunduk dan patuh hanya kepada Allah. Pada tahap ini jiwa berada pada tahap paling tenang. Manakala al-nafs al-lawwāmah ialah jiwa pada tahap pertengahan, juga dikatakan nafsu orang awam yang mana imannya naik dan turun. Pada tahap ini, seseorang sedang berusaha untuk melawan segala godaan kejahatan, untuk mencapai tahap jiwa yang terbaik. Tahap jiwa yang terakhir ialah al-nafs al-

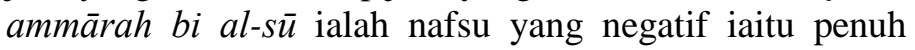
dengan keinginan, kemarahan dan negatif ${ }^{49}$.

Istilah yang terakhir ialah akal ('aql) yang merupakan satu anugerah kurniaan Allah kepada manusia bagi membezakan antara manusia dan haiwan. Al-`aql adalah tempat maklumat dan pengetahuan berkembang. Keistimewaan akal ini adalah untuk berfikir, menghayati dan memikul tanggungjawab. Maksud akal yang pertama adalah ilmu pengetahuan tentang hakikat sebenar sesuatu perkara $^{50}$. Akal menggambarkan realiti ilmu yang ada

${ }^{47}$ Al-Ghazālì, Ihyā' 'Ulūm al-Dīn, 3, 5.

${ }^{48}$ N. S. Mat Akhir. Al-Ghazali and His Theory of the Soul, 176.

${ }^{49}$ Al-Ghazālì, Ihya '’ 'Ulüm al-Dìn, 3, 5-6.

${ }^{50}$ Ibid., 6, rujuk N. S. Mat Akhir, Al-Ghazali and His Theory of the Soul, 177. 
dalam dada seseorang manusia. Pengertian kedua yang diterangkan oleh al-Ghazāli adalah sifat kedua manusia yang tidak dibincangkan lanjut. Secara kesimpulannya adalah aql merupakan kualiti kecerdasan seseorang dan bagaimana mereka meletakkan perspektif sendiri pada sesuatu perkara tersebut ${ }^{51}$.

Elemen-elemen dalam spiritualiti Islam ini menunjukkan kesatuan atau penglibatan seluruh aspek dalaman diri seseorang manusia dalam usaha merasai, mendalami dan menghayati kerohanian dalam agama. Elemen transenden dalam spiritualiti umum menyamai elemen rūh dalam spiritual Islam, manakala elemen nilai menyamai ‘al kerana asas nilai adalah pada akal yang berfikir. Didikan yang ditekankan oleh al-Ghazāli bagi membimbing empat aspek utama spiritual ('aql, nafs, qalb dan $r \bar{u} h$ ) mempunyai tiga proses utama iaitu pembersihan jiwa (tazkiyah al-nafs), berjihad melawan nafsu (mujahādah al-nafs) dan latihan jiwa (riyādah al-nafs). ${ }^{52}$

Proses ini sangat berkait dengan proses takhalli (mengosongkan diri dari perbuatan keji dan sikap negatif) dan tahalli (pengisian jiwa dengan ibadah dan amal soleh) yang juga digariskan oleh Imam al-Ghazāli dalam kitab Ihya ' 'Ulūm al-Dìn. Takhalli adalah proses yang menyamai konsep tazkiyah al-nafs, manakala tahalli menyamai riyādah al-nafs. ${ }^{53}$

Konsep mujahādah al-nafs dan riyādah al-nafs dalam mengawal masalah dan kesakitan juga sangat memberi manfaat kepada pesakit yang kritikal. Mujāhādah al-nafs bermaksud berusaha melawan dan menahan diri dari sesuatu yang negatif. Sebagai contoh seorang pesakit memang tidak dapat membohongi diri untuk mengatakan

${ }^{51}$ N. S. Mat Akhir. Al-Ghazali and His Theory of the Soul, 178.

52 S. B. S. Muhsin \& C. Z. Sa'ari, "Beberapa Aspek Psikoterapi Islam dalam Kitab Jawi, 'Penawar Bagi Hati' oleh Sheikh Abdul Qadir AlMandili," Jurnal Afkar, 14, (2013), 135-137.

53 I. H. Ahmad, "Ketenteraman Jiwa dalam Perspektif Al-Ghazali," Jurnal Substantia, 12(1) (2011), 116. 
tidak sakit dan sihat, akan tetapi konsep mujāhāadah al-nafs ini mengambil kira sikap tidak putus asa dan lawan rasa untuk berhenti berusaha dalam mencari penawar. Konsep riyādah al-nafs pula ialah usaha melatih diri yang dalam keadaan sakit dan tidak selesa secara positif. Antaranya dengan cara melakukan amal ibadah dan zikir bagi melatih diri untuk sentiasa berusaha bersikap sabar dengan ujian tersebut. Selain itu ialah melatih diri untuk positif dan kembali kepada masyarakat untuk menyumbang.

Akal adalah punca intelektual dan berfikir, nafsu adalah tempat bermulanya emosi, hati adalah punca segala tindakan dan spiritual rohani adalah panduan utama. Memfungsikan secara keseluruhannya akan membantu seseorang dalam memperolehi ketenangan dan kualiti kehidupan yang lebih baik. Muhammad Rifa'at menerangkan konsep targhỉb yang dibawa oleh Badi'uzzaman Sa'id Nursi, bermaksud memupuk galakan dan perangsang sehingga seseorang pesakit meletakkan pengharapan dan pergantungan hanya kepada Allah. ${ }^{54}$

Konsep ini adalah dalam proses riyādah al-nafs seperti yang digariskan oleh Imam al-Ghazālì. Justeru, sikap sabar, redha, tawakkal dan pengharapan pada kepada Allah akan menghiasi seseorang individu melalui didikan spiritual ini. Sifat-sifat positif yang terzahir akan menenggelamkan aura negatif yang datang dari kesakitan fizikal.

\section{Kesan Kekurangan Aspek Spiritual Dalam Paliatif}

Kesan kesakitan boleh dilihat dari pelbagai aspek seperti fizikal, emosi, psikologi, spiritual dan kehidupan sosial pesakit. Kesihatan fizikal secara umumnya adalah dipengaruhi oleh emosi, psikologi dan spiritual pesakit. Antara simptom-simptom fizikal seorang pesakit ialah ia sering keletihan, tidur terganggu, kurang makan, sering

\footnotetext{
${ }^{54}$ M. R. Razman \& S. H. Hamjah, "Dakwah dalam Dimensi Kerohanian Penjagaan Paliatif," 36.
} 
muntah dan lain-lain. ${ }^{55}$ Kesakitan dari segi fizikal tersebut akan menjejaskan kualiti hidup seseorang terutama yang melibatkan kehidupan sosial, seperti tidak dapat menjalani kehidupan seharian biasa iaitu bekerja, belajar, bercuti, beraktiviti luar, makan hidangan yang digemari dan bergaul bersama ahli keluarga dan kawan-kawan.

Perubahan aspek kemampuan fizikal dapat dilihat membawa kesan kepada kehidupan seharian, dan semestinya akan membawa perubahan besar terhadap emosi, psikologi dan spiritual. Hal ini kerana setiap apa yang ingin dilakukan dirasakan tersekat dan terhalang, seterusnya menimbulkan rasa tidak bebas, kecewa, marah, rasa terbeban dan menyusahkan, rasa terasing dan keseorangan, rasa kehilangan, rasa tidak tenang, resah dan hilang kawalan dengan menyalahkan diri sendiri dan rasa marah terhadap takdir.

Apa yang dilalui ini menyebabkan munculnya ketidakpuasan hati dan tidak mampu memberi ketenangan kepada jiwa serta dalaman seseorang, dan menyebabkan berlakunya keresahan spiritual, ${ }^{56}$ iaitu spiritual distress dalam istilah perubatan. Maksud lain, keresahan spiritual berlaku apabila keperluan-keperluan spiritual tidak dapat dipenuhi. Apabila seseorang itu mengalami keresahan spiritual, kesannya akan kembali kepada fizikal yang bertambah sakit, emosi semakin kurang stabil, akal yang tidak mampu berfikir dengan baik dan kehidupan sosial berubah. Masalah pada fizikal, emosi, psikologi dan spiritual adalah saling berkait dan saling memberi kesan, bukanlah bergantung kepada satu aspek sahaja.

55 C. Schulz, D. Schlieper \& C. Altreuther, "The Characteristics of Patients Who Discontinue Their Dying Process - An Observational Study at a Single University Hospital Centre," BMC Palliat Care, 14 (2015), 3. doi:10.1186/s12904-015-0070-7.

56 S. Monod, E. Martin, B. Spencer et al., "Validation of the Spiritual Distress Assessment Tool in Older Hospitalized Patients," BMC Geriatrics, 12(1) (2012), 2. doi:10.1186/1471-2318-12-13. 
Keadaan sakit yang melibatkan semua aspek ini adalah disebut sebagai kesakitan yang menyeluruh (total pain). ${ }^{57}$ Untuk merawat kesakitan ini, para pengamal perubatan dan keluarga terutamanya mesti mengesan punca utama yang bermasalah atau sakit serta penderitaan yang dialami dari semua aspek fizikal, emosi, spiritual dan juga lingkungan sosial individu tersebut. Simptom gangguan spiritual yang dialami dikenalpasti berdasarkan keperluan-keperluan spiritual yang telah dibincangkan oleh para sarjana seperti Monod, ${ }^{58}$ Allan Kellehear, ${ }^{59}$ Anandarajah, ${ }^{60}$ Peterman, ${ }^{61}$ Liwliwa, ${ }^{62}$ Borneman, ${ }^{63}$ Mark Cobb ${ }^{64}$ dan Silvia ${ }^{65}$

Manakala Salasiah dalam tulisannya berkenaan bimbingan spiritual berdasarkan al-Ghazāli, menyatakan masalah yang dihadapi oleh seorang manusia itu bukanlah datang daripada lahiriah atau fizikal semata, namun dipengaruhi oleh spiritual iaitu soal hati dan emosi, ${ }^{66}$ iaitu seseorang tidak dapat mengawal perasaan negatif seperti

${ }^{57}$ C. Faull \& R. Woof, Palliative Care (New York: Oxford Handbook of Clinical Medicine, 2002), 4.

58 S. Monod, E. Rochat, C. Büla, \& B. Spencer, "The Spiritual Needs Model," 275-276.

59 A. Kellehear, "Spirituality and Palliative Care: A Model of Needs. Palliative Medicine," 14(2) (2000), 152. doi:10.1191/026921600674786394

${ }^{60}$ G. Anandarajah \& E. Hight, "Spirituality and Medical Practice," 86.

${ }^{61}$ S. Monod et al. "The Spiritual Needs Model," 52.

${ }^{62}$ L. R. Villagomeza, "Spiritual Distress in Adult Cancer Patients," 287.

63 Tami Borneman, "Evaluation of the FICA Tool for Spiritual Assessment," Journal of Pain and Symptom Management, 40(2) (2010), 166. doi:10.1016/j.jpainsymman.2009.12.019

64 M. Cobb, C. Dowrick, \& M. Lloyd-Williams, "Understanding Spirituality: A Synoptic View," BMJ Support Palliat Care, 2(4) (2012), 340. doi:10.1136/bmjspcare-2012-000225

${ }^{65}$ S. Caldeira et al., "Spiritual Distress-Proposing A New Definition and Defining Characteristics," 82.

66 S. H. Hamjah, "Bimbingan Spiritual Menurut al-Ghazali dan Hubungannya dengan Keberkesanan Kaunseling: Satu Kajian di Pusat Kaunseling Majlis Agama Islam Negeri Sembilan (PK MAINS)," Jurnal Islamiyyat, 32 (2010), 45. 
menggunakan bahasa kasar terhadap orang lain dan juga seseorang itu akan merasai tiada ketenangan dan kebahagiaan dalam menjalani kehidupan.

Sharifah Basirah dan Che Zarrina pula ada membincangkan kesan kekurangan spiritual atau kerohanian dalam diri yang mana menyebabkan seseorang itu mengalami gangguan kejiwaan yang dizahirkan melalui perbuatan iaitu akan menjadi muram, sedih, pilu, cemas, resah, gelisah hati dan jiwa tidak tenteram. Gangguan emosi ini akan menyebabkan seseorang itu akan rasa tidak bermaya untuk meneruskan kehidupan dan hal ini akan menyebabkan seseorang itu seolah-olah tiada matlamat dan tujuan untuk hidup. ${ }^{67}$ Justeru, ketenangan dan kebahagiaan di dunia dan akhirat yang menjadi impian semua individu tidak akan diperolehi sekiranya masalah dalam jiwa tidak dapat diatasi.

Kesan kekurangan aspek spiritual adalah hampir sama bagi semua pengkaji dan sarjana, kerana kesan dan ciricirinya adalah pada tingkah laku manusia itu sendiri. Penilaian kepada punca berlaku keresahan spiritual, cara untuk mengawal dan merawat adalah berbeza bagi para sarjana kerana pemikiran dan kefahaman adalah berbeza. Bagi sarjana Barat, aspek boleh dilihat kaitan kepada masalah spiritual adalah seluruh aspek kehidupan, sama ada tidak bersedia untuk meninggalkan komitmen kehidupan terhadap keluarga, kehidupan normal seperti pekerjaan dan lain-lain. Manakala pandangan sarjana Muslim adalah lebih kepada masalah punca asas kepercayaan dalam kehidupan yang terganggu, iaitu dalam aspek konsep takdir dan redha.

\section{Peranan Spiritual Dalam Paliatif}

Setiap individu termasuk pesakit, pengamal perubatan dan orang sekeliling sama ada keluarga, kawan dan sukarelawan mempunyai peranan masing-masing dalam

${ }^{67}$ S. B. S. Muhsin \& C. Z. Sa'ari, "Beberapa Aspek Psikoterapi Islam dalam Kitab Jawi,” 127. 
penjagaan paliatif. Penting untuk mereka mengetahui peranan yang mesti dilakukan pada setiap posisi dan keadaan pesakit. Terutamanya dalam aspek kesejahteraan spiritual seorang pesakit mestilah mendapat sokongan padu dari semua yang terlibat. Hal ini kerana dalam fasa yang kritikal, pesakit akan mempunyai masalah dalam membuat keputusan dan berfikir secara rasional. Begitu juga setiap individu yang terlibat juga saling memerlukan sokongan dan bantuan ${ }^{68}$.

Fasa-fasa penerimaan yang dilalui oleh pesakit adalah berubah-ubah bermula daripada awal pengenalpastian penyakit kritikal, semasa menjalani sesi rawatan sehinggalah pada akhir hayat kehidupan. Pada setiap fasa inilah terdapat peranan setiap individu yang berada disekeliling pesakit dari semua aspek, khususnya aspek spiritual. Antara fasa yang digariskan oleh Kubbler-Ross ${ }^{69}$ ialah pengingkaran (denial), marah dan iri (anger), tawar menawar (bargaining), kemurungan (depression) dan akhir sekali penerimaan (acceptance). Setiap fasa ini adalah berbeza cara yang dilakukan oleh setiap pesakit kerana perbezaan kepercayaan, latar belakang dan pengalaman kehidupan yang dilalui. ${ }^{70}$ Situasi dan pengertian bagi setiap fasa akan diterangkan dengan lebih terperinci dalam perbincangan seterusnya.

Pengingkaran (denial) ialah fasa pesakit menafikan secara keras keputusan hasil diagnosis penyakit akhir hayat yang dihidapi. Pesakit tidak dapat menerima hakikat dengan dugaan sakit yang dialami ${ }^{71}$. Pada fasa ini merupakan fasa yang pesakit tidak mahu berinteraksi

68 C. L. Gales, S. Resnikoff \& C. Sepulveda, "Cancer Control Knowledge into Action," dalam WHO Guide for Effective Programmes, ed. W.H.O. (Switzerland: WHO Press, World Health Organization, 2007).

${ }^{69}$ C. Faull \& R. Woof. Palliative Care, 5.

70 C. N. Fitria, "Palliative Care Pada Penderita Penyakit Terminal," GASTER, 7(1) (2010), 528.

${ }^{71}$ C. Faull \& R. Woof. Palliative Care, 5. 
dengan sesiapa termasuk ahli keluarga dan rakan-rakan. Penerapan aspek spiritual pada fasa ini juga memakan masa untuk menerangkan kepada pesakit. Pesakit mengambil masa untuk menerima hakikat keadaan dirinya yang ditimpa ujian kesakitan tersebut. Pada fasa ini, ahli keluarga pesakit adalah orang yang terdekat yang mesti menunjukkan sokongan penuh melalui komunikasi dan tindakan dalam menghadapi penyakit ini agar pesakit merasakan dia tidak sendiri menghadapinya.

Apabila ditimpa sebarang musibah, Islam mengajar agar umatnya bersabar dan bersangka baik dengan Yang Maha Menjadikan Sesuatu seperti penyakit kritikal. Kajian demi kajian bagi mencari jalan penyelesaian untuk mengawal sakit dari pelbagai aspek seperti aspek spiritual dan emosi, namun semua itu adalah bermula dari dalam diri individu tersebut bagaimana mahu mengambil pengajaran dan bertindak dengan situasi. Justeru didikan kerohanian dari aspek keagaaman amat penting bagi memastikan ada pegangan asas yang mengawal tindakan individu itu sendiri. Ahli keluarga dan orang terdekat juga sangat penting mempunyai ilmu dan pengetahuan berkait dengan kerohanian dan keagaaman bagi membantu pesakit menghadapi ujian ini.

Fasa kedua ialah pesakit akan sering marah (anger) dengan keadaan dirinya dan menunjukkan iri terhadap orang lain yang diberi nikmat kesihatan. ${ }^{72}$ Mereka akan sentiasa mengulang-ulang pertanyaan kenapa sakit itu terjadi kepadanya. Mereka rasa kekecewaan dengan sendiri dan mula menyalah diri sendiri dengan kesilapan-kesilapan lalu. Pada fasa ini juga menghadapi masalah untuk penekanan aspek spiritual. Pesakit tidak dapat menerima hakikat keadaan dirinya yang diambang kematian. Pada fasa ini ahli keluarga dan kenalan terdekat mestilah sentiasa bersama pesakit bagi membantu meneutralkan kemarahan dan mempositifkan persoalan yang terluah oleh pesakit.

${ }^{72}$ Ibid.. 
Kemarahan yang dihuraikan dalam Islam adalah suatu emosi yang berpunca dari jiwa yang tidak tenang. Manakala, perasaan iri dengan nasib orang lain pula adalah seolah-olah berperang dengan diri sendiri ${ }^{73}$ dan seoalaholah marah dengan apa yang Allah takdirkan kepadanya. Sikap-sikap seperti ini seolah-olah menyakitkan diri sendiri kerana apa yang berlaku tidak boleh diubah atau diubati dengan cara seperti itu. Sebaliknya Islam mengajar umatnya sabar $(s a b r)$ dan berharap $(r a j \bar{a})^{74}$ dengan cara berusaha mencari penawar dan alternatif lain bagi mengawal penyakit tersebut.

Fasa seterusnya adalah fasa tawar menawar (bargaining) iaitu fasa pesakit lebih tenang. Pesakit akan cuba meminta agar penyakitnya disembuhkan dengan apa jua cara. Pesakit akan mula banyak berinteraksi pada fasa ini kerana mengharapkan sesuatu yang lebih baik seperti sembuh sepenuhnya dari penyakit tersebut. Kebiasaanya applikasi spiritual mudah untuk diterapkan ketika fasa tawar menawar ini. ${ }^{75}$ Pesakit lebih mudah mendengar dan menerima pandangan sekeliling sama ada dari doktor, keluarga dan lain-lain yang terdekat dengan pesakit. Jangka masa peralihan daripada fasa kedua kepada fasa ketiga adalah bergantung kepada semangat pesakit itu sendiri dan juga sokongan daripada orang sekeliling.

Mohamad Zafir antara tokoh sarjana Islam yang membincangkan aspek kesihatan dan menekankan kaitan

${ }^{73}$ S. B. S. Muhsin \& C. Z. Sa'ari, Kaedah Psikoterapi Islam berasaskan Konsep Maqamat Abu Talib Al-Makki (Kuala Lumpur: Dewan Bahasa dan Pustaka, 2015), 161.

${ }^{74}$ C. Z. Sa'ari \& S. B. Syed Muhsin, "Cadangan Model Psikoterapi Remaja Islam Berasaskan Konsep Tazkiyah al-Nafs," Jurnal Usuluddin, 36 (2012), 65.

75 A. C. Bloemhard, The Care That Shines From Within: The Role of Spirituality in Aged and Palliative Care: A Qualitative Study That Explores How Spirituality Informs Care-Giving to the Elderly and Dying in Home and Residential Care in A Regional Area on the Mid North Coast of New South Wales (Master of Arts, Southern Cross University, Australia, 2008), 5. 
serta peri penting spiritual dalam aspek penjagaan kesihatan dan kualiti kehidupan. ${ }^{76}$ Zafir menekankan kepentingan pengamalan amalan kerohanian dalam proses penyembuhan seperti membaca al-Qur'an dan doa-doa tertentu. Sebagai ummat Islam, semestinya mengamalkan dan yakin dengan janji-janji dalam kitab utama seperti alQur'an dan hadis Rasulullah SAW. Terapi dan amalan positif yang berterusan akan membantu meningkatkan kualiti hidup kerana ianya sumber kekuatan seseorang.

Kemurungan (depression) ialah fasa selepas pesakit cuba mengadakan tawar-menawar dengan orang lain, di mana pesakit menyedari bahawa penyakit yang dialami adalah mempunyai harapan yang tipis. Pada fasa ini, pesakit akan mengalami kemurungan, kebimbangan, putus harap dan rasa berdosa. Kemurungan ini akan membawa pesakit itu kepada tekanan dan keresahan serta cenderung ke arah sesuatu yang negative. ${ }^{77}$ Tindakbalas pesakit pada fasa ini sangat bergantung kepada penghayatan aspek spiritual pada fasa tawar-menawar. Hal ini kerana cubaan membunuh diri pernah dilakukan oleh pesakit yang tidak dapat menahan perasaan dan kesakitan pada fasa ini. ${ }^{78}$

Pesakit mesti berusaha untuk mengawal kemurungan yang melanda dengan cara tersendiri kerana kesannya terhadap proses penyembuhan lebih efektif. ${ }^{79}$ Dalam masa yang sama memerlukan sokongan dan bantuan daripada ahli keluarga dan kawan-kawan yang paling rapat. Pengaplikasian konsep psikoterapi juga perlu pada fasa ini, iaitu mujāhadah al-nafs (berusaha melawan) dengan sifat sabar dan riyādah al-nafs (latihan diri) dengan cara melatih

${ }^{76}$ M. Z. Al-Shahri. Culturally Sensitive Caring for Saudi Patients, 134.

77 I. McDowell, Measuring Health: A Guide to Rating Scales and Questionnaires (New York: Oxford University Press, 2006), 21.

${ }^{78}$ M. S. Mahajudin, "Peran Psikogeriatri \& Perawatan Paliatif," 290.

${ }^{79}$ E. Chambers, S. Cook, \& A. Thake, "The Self-management of LongerTerm Depression: Learning from the Patient, A Qualitative Study," BMC Psychiatry, 15(172) (2015), 2. doi:10.1186/s12888-015-0550-6 
diri memperbanyakkan amal kebaikan dan sifat yang positif. $^{80}$

Penerimaan (acceptance) adalah fasa terakhir dalam peringkat menghampiri kematian. Pesakit telah melalui fasa-fasa sebelum ini dengan penuh emosi dan mencuba pelbagai cara dalam usaha untuk menerima hakikat kesakitan yang dialami. ${ }^{81}$ Pesakit boleh menerima hakikat menjadikan pesakit lebih tenang. Ada pesakit yang tidak takut akan kematian itu berlaku, namun takut akan fasa kesakitan menghampiri kematian itu kerana proses yang lama dan menyakitkan. ${ }^{82}$ Dalam fasa terakhir ini, pesakit lebih mudah untuk diterapkan dengan aspek spiritual kerana mereka lebih mencari sesuatu yang lebih menenangkan mereka. Pada saat akhir, pesakit sendiri akan mula beralih fokus dan memerlukan perhatian dalam aspek spiritual. ${ }^{83}$

Menjadi suatu kemestian seorang muslim meyakini kesakitan atau penderitaan adalah suatu takdir dan perancangan dari Allah sebagai salah satu jalan penghapus dosa-dosa dan kesalahan serta menaikkan seorang manusia itu ke darjat yang lebih mulia. Amalan yang ditekankan sepanjang menghadapi ujian kehidupan, seorang Muslim mesti menjalankan tuntutan sebagai seorang hamba dalam Rukun Islam ${ }^{84}$ sehabis boleh. Komaruddin Hidayat menyatakan bahawa saat yang paling sedih adalah apabila seseorang terpaksa mengorbankan apa yang disayanginya seperti ahli keluarga, iaitu pesakit sayang dan sedih apabila

${ }^{80}$ S. B. S. Muhsin \& C. Z. Sa'ari, "Beberapa Aspek Psikoterapi Islam dalam Kitab Jawi," 115.

${ }^{81}$ C. Faull \& R. Woof. Palliative Care, 5.

82 Pam McGrath, "Spiritual Pain: A Comparison of Findings from Survivors and Hospice Patients," American Journal of Hospice \& Palliative Care, 20(1) (2003), 28.

${ }^{83}$ A. Edwards, "The Understanding of Spirituality and the Potential Role of Spiritual Care," 1.

84 K. Hidayat, Psikologi Kematian (Jakarta Selatan: Penerbit Noura Books, 2015). 
merasakan dia akan berpisah sedangkan mereka masih banyak ingin berbakti kepada ahli keluarga. ${ }^{85}$

Usaha yang dilakukan mesti melibatkan pesakit, ahli keluarga, sukarelawan dan khususnya penglibatan oleh pakar-pakar yang diperlukan seperti pengamal perubatan, kaunselor, orang yang boleh membimbing aspek keagamaan dan lain-lain. Setiap dimensi dalam penjagaan sangat penting dan memerlukan kerjasama oleh individu dan kepakaran yang terlibat bagi mendapatkan impak yang positif kepada pesakit dalam usaha memberi kebahagian dan keselesaan kepada pesakit dan juga keluarga yang berdepan dengan penyakit kritikal. ${ }^{86}$ Murray dalam kajiannya menyatakan kepercayaan agama yang kuat akan memberi kesan positif terhadap kesihatan fizikal dan mental serta kualiti hidup. ${ }^{87}$

Islam mengajar umatnya untuk mengamalkan cara hidup Islam sesama masyarakat seperti memenuhi hak-hak seorang Muslim. Berdasarkan hadis Rasulullah SAW yang bermaksud, "Hak sesama muslim adalah menjawab dan memberi salam, mengucap balas apabila seseorang itu bersin dan mengucapkan 'alhamdulillah', memberi nasihat apabila diminta, menziarahi ketika sakit, menguruskan jenazah apabila berlaku kematian". ${ }^{88}$ Setiap perkara yang dianjurkan untuk dilaksanakan dalam hadis ini sangat besar manfaatnya sesama Muslim. Contohnya kebaikan menziarahi sangat besar hikmahnya, kerana ketika

\footnotetext{
${ }^{85}$ Ibid.

${ }^{86}$ Robin B. Rome, Hillary H. Luminais, Deborah A. Bourgeois \& Christopher M. Blais, "The Role of Palliative Care at the End of Life," The Ochsner Journal, 11 (2011), 348.

${ }^{87}$ S. A. Murray, M. Kendall \& K. Boyd, "Exploring the Spiritual Needs of People Dying of Lung Cancer or Heart Failure a Prospective Qualitative Interview Study of Patients and Their Carers," Palliative Medicine, 18 (2004), 39.

${ }^{88}$ Al-Qārī, "Kitāb Janā'iz Bāb 'Iyādah al-Marị̣ wa Thawāb al-Mariḍ̂," dalam Sharah Mishkāt al-Mașābīh 4, ed. S. J. `Aythanī (Beirut: Dār al-Kutub al-`Ilmiyyah, 2002), 3.
} 
menziarah, tetamu saling mendoakan, saling membantu dan memberi sokongan moral kepada pesakit.

Setiap fasa yang dihadapi adalah suatu perkara normal bagi setiap pesakit, namun jangka masa yang dilalui bagi setiap fasa adalah bergantung kepada kondisi spiritual pesakit. Allah berfirman berkenaan apa jua yang Allah bebani hamba-Nya adalah bersesuaian dengan keupayaannya, iaitu dalam Surah al-Baqarah ayat 286, yang bermaksud "Allah tidak akan memberati seseorang melainkan apa yang terdaya olehnya, ia mendapat pahala kebaikan yang diusahakannya dan ia juga menanggung dosa kejahatan yang diusahakannya".

Sepanjang fasa yang dilalui, perubahan positif pada diri dan keadaan pesakit dan ahli keluarga pesakit adalah fokus utama, terutamanya naik turun perubahan fizikal, emosi dan spiritual pesakit. Satu kajian oleh Gysels et al. menunjukkan pesakit tahu bahawa mereka perlu merancang apa yang perlu dilakukan bagi mengatasi rasa sakit dan mengawal tekanan yang dialami. ${ }^{89}$ Terutamanya penekanan aspek spiritual pesakit mesti dibimbing dan lebih baik dilakukan bersama dengan pesakit bagi memudahkan untuk menyalurkan sokongan dan bantuan.

Ahli keluarga dan kawan-kawan adalah antara orang yang dekat dan mengenali pesakit, pada ketika inilah mesti dimanfaatkan sepenuh masa yang ada bersama pesakit untuk membantu dan memberi sokongan penuh kepada pesakit. Antaranya dengan cara mengeratkan ikatan kekeluargaan, kerap melakukan aktiviti bersama seperti rutin harian dan juga amalan pengibadahan. Perkara ini sangat penting bagi mengelakkan pesakit merasa sendirian..$^{90}$ Dengan cara ini juga akan membantu

${ }^{89}$ M. Gysels, I. J. Higginson \& K. MacCormack, Improving Supportive and Palliative Care for Adults with Cancer: The Manual (London: National Institute for Clinical Excellence, 2004), 3.

${ }^{90}$ B. S. R. Paiva, A. L. Carvalho, G. Lucchetti, E. M. Barroso \& C. E. Paiva, ""Oh, yeah, I'm getting closer to God": Spirituality and Religiousness of Family Caregivers of Cancer Patients Undergoing 
menaikkan semangat pesakit dalam menjalankan sesuatu aktiviti. 'Abdullāh Nașị̣ 'Ulwān dalam karangannya berjudul Tarbiyah al-Awlād fi al-Islām ada membincangkan risiko sekiranya seseorang itu keseorangan, maka fikiran mereka akan tersasar ke arah perkara-perkara yang negatif. ${ }^{91}$

Dalam Ulasan al-Hikam karangan Shaykh Ibn Ațā' Allāh oleh Shaykh Sa ìd Hawwā ada menjelaskan berkenaan aspek pemberian atau kurniaan Allah. Apa yang dikurniakan oleh Allah itu adalah dua aspek penilaian, sama ada orang yang menerima itu memandangnya aspek zahir atau aspek batin ${ }^{92}$. Pesakit Muslim perlu untuk kerap diingatkan tentang perkara tersebut bagi memastikan mereka sentiasa yakin dengan apa yang Allah janjikan dan redha dengan takdir. Cara yang boleh dilakukan ialah dengan meletakkan tawakkal dan redha yang tinggi mutlak kepada Allah, serta yakin akan ganjaran daripada Allah. Konsep tawakkal ${ }^{93}$ seperti diterangkan oleh Idrus Ahmad, ialah Allah yang mengatur seluruh kehidupan manusia dan apa yang ditakdirkan itu adalah dalam perancanganNya.

Manakala sebagai pengamal perubatan atau doktor yang merawat pesakit perlu memahami situasi spiritual pesakit dan keluarga pesakit. ${ }^{94}$ Pengamal perubatan akan memainkan peranan bagi mengkaji perincian perancangan perubatan dan rawatan bagi membantu aspek fizikal pesakit. Dalam masa yang sama pengamal perubatan mestilah mengesan perubahan-perubahan spiritual

Palliative Care," Supportive Care in Cancer, 23(8) (2015), 2385. doi:10.1007/s00520-015-2604-1

${ }^{91}$ A. N. 'Ulwan, Tarbiyatu 'l-Aulad fi 'l-Islam, terj. S. Kamalie \& H. N. Ali (Kuala Lumpur: Victory Agencie, 1996), 244.

${ }^{92}$ Sa'id Hawa, Ulasan Al-Hikam (Kata-kata Hikmah Syeikh ibn Ata'illah Al-Sakandari (Johor: Perniagaan Jahabersa, 2002), Fasal VIII, Bab II, 270.

${ }^{93}$ I. H. Ahmad, "Ketenteraman Jiwa dalam Perspektif al-Ghazali," 121.

${ }^{94}$ G. Anandarajah \& E. Hight, "Spirituality and Medical Practice," 81. 
pesakit, ${ }^{95}$ di samping memberi nasihat serta sokongan moral kepada pesakit sepanjang menjalankan rawatan kepada pesakit. Sukarelawan yang sedia turun ke lapangan untuk membantu para pesakit kritikal mesti belajar dan mendalami setiap fasa dan keadaan pesakit bagi memudahkan proses rawatan, terutamanya antara sukeralawan yang diperlukan ialah pakar dalam penjagaan agama ${ }^{96}$ seperti pendakwah, kaunselor dan lain-lain.

Antara peranan mereka ialah memberi penerangan kepada para pengamal perubatan, ahli keluarga dan golongan sukarelawan yang lain berkenaan norma-norma atau adat yang mesti dijaga bagi menunjukkan rasa hormat dan penghargaan, kasih sayang dan sokongan kita kepada pesakit. Selain itu ialah para ahli agama mestilah merancang bagi mengurangkan penderitaan spiritual pesakit dan keluarga dengan cara menekankan aspek keyakinan dan harapan. Aspek kepercayaan dan pengibadahan juga mesti dibimbing oleh golongan ahli agama ini agar pesakit tidak merasa hilang kekosongan dan teguh berpegang pada kepercayaan dan keimanan. ${ }^{97} \mathrm{Hal}$ ini kerana sumber kekuatan dalaman adalah datang daripada pegangan agama yang teguh.

Schulz menyatakan antara masalah ialah tindakan yang diperlukan untuk mengenalpasti keadaan pesakit sepenuhnya dan merancang strategi terbaik untuk membantu pesakit yang mengambil masa yang agak panjang kerana bergantung kepada situasi pesakit dan keluarga. ${ }^{98}$ Justeru pengamal perubatan berperanan dalam usaha menerangkan kebaikan serta menyediakan perancangan yang strategik bagi membantu pesakit.

95 Ibid.

96 B. Pesut, S. Sinclair \& G. Fitchett, "Health Care Chaplaincy: A Scoping Review of the Evidence 2009-2014," J Health Care Chaplain, 22(2) (2016), 76. doi:10.1080/08854726.2015.1133185

${ }^{97}$ L. R. Villagomeza, "Spiritual Distress in Adult Cancer Patients," 289.

${ }^{98}$ C. Schulz et al., "The Characteristics of Patients," 7. 
Kesimpulannya, setiap individu yang terlibat dengan kehidupan sosial pesakit mestilah saling bekerjasama dan menjalankan tanggungjawab memberi bantuan dan sokongan kepada pesakit. Aspek spiritual dalam diri ahli keluarga, rakan-rakan, pengamal perubatan dan sukarelawan seharusnya juga sentiasa berada pada tahap maksima sebelum menemui pesakit bagi mengalirkan aura yang positif kepada pesakit dan mengelakkan pesakit lemah semangat sekiranya orang yang menemui pesakit dalam situasi yang lemah dan sedih.

\section{Kesimpulan}

Penjagaan paliatif merupakan alternatif dan usaha yang terbaik dalam membantu pesakit berpenyakit terminal kerana pendekatan dari semua sudut ditekankan. Pelbagai modul penjagaan paliatif telah digubal dan diaplikasikan kepada para pesakit, contohnya terapi muzik ${ }^{99}$ membantu dalam ketenangan fikiran seterusnya mengurangkan kesakitan dan terapi 'dignity' 100 yang membantu mengurangkan tekanan spiritual. Semua ini adalah bagi membantu meringankan bebanan sakit yang ditanggung oleh pesakit. Terutamanya modul spiritual bagi memulihkan semangat pesakit. Lima kategori yang dititikberatkan dalam penjagaan spiritual ${ }^{101}$ ialah model penjagaan dan perancangan penjagaan, latihan pasukan interprofesional, penambahbaikan kualiti serta pembangunan peribadi dan profesional.

Antara cadangan bagi membangunkan modul untuk pesakit ialah modul psikoterapi Islam iaitu berkonsepkan

99 D. Aldridge, "Spirituality, Hope and Music-Therapy in Palliative Care," Arts in Psychotherapy, 22(2) (1995), 103. doi:10.1016/01974556(95)00009-t

${ }^{100}$ M. Thomas, S. A. Irwin \& E. A. Meier, "Enhancing Legacy in Palliative Care: Study Protocol for a Randomized Controlled Trial of Dignity Therapy Focused on Positive Outcomes," Bmc Palliative Care, 14(44) (2015), 1.

${ }^{101}$ C. Puchalski et al., "Improving the Quality of Spiritual Care as a Dimension of Palliative Care," 885. 
penerapan terapi agama. Pendekatan psikoterapi Islam akan membantu proses rawatan atau terapi yang efektif bagi penyakit rohani atau spiritual, juga bagi penyakit jasmani. Apabila aspek pendekatan spiritual kurang dititikberatkan, segala modul fizikal, psikologi dan lain-lain akan menjadi kurang berkesan kerana perubahan dalam diri pesakit adalah berpunca daripada spiritual dalam diri pesakit itu sendiri berdasarkan yang telah dibincangkan di atas. Psikoterapi Islam adalah modul yang menitikberatkan konsistensi dalam amalan dan ritual sehingga mendatangkan perubahan dalam diri seseorang.

Modul psikoterapi Islam berdasarkan ajaran ulamaulama Islam terdahulu adalah menekankan beberapa elemen penting dalam pelaksanaan. Sebagai contoh Syeikh 'Abdul Qadir Al-Mandili menekankan tazkiyah al-nafs, mujāhadah al-nafs dan riyādah al-nafs dalam elemen psikoterapinya, manakala Abū Ṭālib al-Makkì membawa elemen maqāmāt dalam pendekatan psikoterapinya. Elemen maqāmāt ialah rajā' iaitu kembali kepada Pencipta dengan penuh harapan. Imam al-Ghazāli pula membawa aspek tazkiyah al-nafs dalam pendekatan psikoterapinya. Semua penekanan elemen tersebut adalah bertujuan untuk mencapai ketenangan dan kebahagiaan hakiki di dunia dan akhirat.

\section{Rujukan}

Ahmad, I. H., "Ketenteraman Jiwa dalam Perspektif AlGhazali," Jurnal Substantia 12(1) (2011):115-125.

Aldridge, D., "Spirituality, Hope and Music-Therapy in Palliative Care," Arts in Psychotherapy 22(2) (1995):103-109. doi:10.1016/0197-4556(95)00009-t

Anandarajah, G. \& Hight, E., "Spirituality and Medical Practice: Using the HOPE Questions as a Practical Tool for Spiritual Assessment," American Family Physician. 63(1) (2001):81-88.

Auda, J. Maqasid al-Shariah: An Introductory Guide. Herndon: IIIT, 2008. 
Bloemhard, A. C. The Care That Shines from Within: The Role of Spirituality in Aged and Palliative Care: A Qualitative Study That Explores How Spirituality Informs Care-Giving to the Elderly and Dying in Home and Residential Care in A Regional Area on the Mid North Coast of New South Wales. (Master of Arts, Southern Cross University, Australia, 2008). (Master of Arts), Southern Cross University, Australia, 2008.

Breitbart, W., "The Goals of Palliative Care: Beyond Symptom Control," Palliative \& Supportive Care 4(01) (2006):1-2. doi:10.1017/S1478951506060019

Caldeira, S., Carvalho, E. C. \& Vieira, M., "Spiritual Distress-proposing a New Definition and Defining Characteristics," International Journal of Nursing Knowledge 24(2) (2013):77-84.

Chambers, E., Cook, S., \& Thake, A., "The SelfManagement of Longer-Term Depression: Learning from the Patient, A Qualitative Study," BMC Psychiatry, 15, (2015):172. doi:10.1186/s12888-015-0550-6

Cobb, M., Dowrick, C. \& Lloyd-Williams, M., "Understanding Spirituality: A Synoptic View," BMJ Support Palliat Care 2(4) (2012):339-343. doi:10.1136/bmjspcare-2012-000225

Dain, R., "Penjagaan Paliatif beri Kelegaan Pesakit," Utusan Online. (2011, 27 October). Diakses 2 Disember 2014 daripada http://ww1.utusan.com.my/utusan/info.asp?y=2011\&dt $=1027 \&$ pub $=$ Utusan_Malaysia\&sec $=$ Kesihatan $\& p g=k n$ _01.htm

Edwards, A., Pang, N., Shiu, V. \& Chan, C., "The Understanding of Spirituality and the Potential Role of Spiritual Care in End-of-life and Palliative Care: A Metastudy of Qualitative Research," Palliative Medicine. 24(8) (2010):753-770. doi:10.1177/0269216310375860

Emanuel, L., Handzo, G. \& Grant, G., "Workings of the Human Spirit in Palliative Care Situations: A Consensus 
Model from the Chaplaincy Research Consortium," BMC Palliative Care. 14 (2015):13. doi:10.1186/s12904-015-0005-3

Faull, C. \& Woof, R. Palliative Care. New York: Oxford Handbook of Clinical Medicine, 2002.

Faull, C., Carter, Y. \& Woof, R. Handbook of Palliative Care. United Kingdom: Blackwell Science, 1998.

Fegg, M., L'hoste, S. \& Brandstatter, M., "Does the Working Environment Influence Health Care Professionals' Values, Meaning in Life and Religiousness? Palliative Care Units Compared with Maternity Wards," Journal of Pain and Symptom Management 48(5) doi:10.1016/j.jpainsymman.2014.01.009

Fitria, C. N., "Palliative Care Pada Penderita Penyakit Terminal," GASTER 7(1) (2010):527 -535.

Franks, Peter J., Nick Bosanquet, C. S., et al., "The Level of Need for Palliative Care: A Systematic Review of the Literature," Palliative Medicine 14 (2000):93-104.

Gales, C. L., Resnikoff, S. \& Sepulveda, C., "Cancer Control Knowledge into Action." In WHO Guide for Effective Programmes, ed. W. H. O. (WHO). Switzerland: WHO Press, World Health Organization, 2007.

Al-Ghazālì. Ihyā' 'Ulūm al-Dīn 3. Damsyik: Maktabat 'Abd al-Wakì al-Darūbì, 1967.

Groot, M. M., Vernooij-Dassen, M. J., Crul, B. J., \& Grol, R. P., "General Practitioners (GPs) and Palliative Care: Perceived Tasks and Barriers in Daily Practice," Palliative Medicine 19(2) (2005):111-118.

Hamjah, S. H., "Bimbingan Spiritual Menurut Al-Ghazali dan Hubungannya dengan Keberkesanan Kaunseling: Satu Kajian di Pusat Kaunseling Majlis Agama Islam Negeri Sembilan (PK MAINS)," Jurnal Islamiyyat 32 (2010): 41-61. 
Hamzah, E. Palliative Care in the Community. Paper presented at the International Conference on Health Sciences, Sunway Pyramid Convention Centre, Subang Jaya, 2005.

Hidayat, K. Psikologi Kematian. Jakarta Selatan: Penerbit Noura Books, 2015.

Kellehear, A., "Spirituality and Palliative Care: A Model of Needs," Palliative Medicine 14(2) (2000):149-155. doi:10.1191/026921600674786394

Lepherd, L., "Spirituality: Everyone has it, but what is it?" International Journal of Nursing Practice 21(5) (2015):566-574. doi:10.1111/ijn.12285

Lukman, H., Latifah \& Nasyirudin, W., "Kesan Terapi Ruqyah dalam Merawat Pesakit HIV AIDS," Jurnal AlHikmah 7(1) (2015):119-131.

Mahajudin, M. S., "Peran Psikogeriatri \& Perawatan Paliatif dalam Upaya Meningkatkan Kesehatan Para Lanjut Usia," Anima, Indonesian Psychological Journal. 23(3) (2008):287-296.

Marsuki, M. Z. \& Ibrahim, M. B., "Falsafah Perubatan Islam Menurut Jalal al-Din al-Suyuti Sebagai Muhaddis al-Asha'irah," KUISAS. (2014):1-10.

Mat Akhir, N. S. Al-Ghazali and His Theory of the Soul: A Comparative Study. Pulau Pinang: Penerbit Universiti Sains Malaysia, 2008.

McDowell, I. Measuring Health: A Guide to Rating Scales and Questionnaires. New York: Oxford University Press, 2006.

Monod, S., Martin, E., Spencer, B. et al., "Validation of the Spiritual Distress Assessment Tool in Older Hospitalized Patients," BMC Geriatrics 12(1) (2012):13. doi:10.1186/1471-2318-12-13

Monod, S., Rochat, E. \& Büla, C., "The Spiritual Needs Model: Spirituality Assessment in the Geriatric Hospital Setting," Journal of Religion, Spirituality \& Aging 22(4) (2010):271-282. doi:10.1080/15528030.2010.509987 
Muhsin, S. B. S. \& Sa'ari, C. Z., "Beberapa Aspek Psikoterapi Islam dalam Kitab Jawi, 'Penawar Bagi Hati' oleh Sheikh Abdul Qadir Al-Mandili," Jurnal Afkar 14 (2013):109-142.

Muhsin, S. B. S. \& Sa'ari, C. Z. Kaedah Psikoterapi Islam Berasaskan Konsep Maqamat Abu Talib Al-Makki. Kuala Lumpur: Dewan Bahasa dan Pustaka, 2015.

Murray, S. A., Kendall, M. \& Boyd, K. Exploring the Spiritual Needs of People Dying of Lung Cancer or Heart Failure a Prospective Qualitative Interview Study of Patients and Their Carers. Palliative Medicine. 18 (2004):39-45.

Padela, A., Gunter, K. \& Killawi, A. Meeting the Healthcare Needs of American Muslims Challenges and Strategies for Healthcare Settings, 2011.

Paiva, B. S. R., Carvalho, A. L., Lucchetti, G., Barroso, E. M. \& Paiva, C. E., ""Oh, yeah, I'm getting closer to god": Spirituality and Religiousness of Family Caregivers of Cancer Patients Undergoing Palliative Care," Supportive Care in Cancer 23(8) (2015):2383-2389. doi:10.1007/s00520-015-2604-1

Pam McGrath, "Spiritual Pain: A Comparison of Findings from Survivors and Hospice Patients," American Journal of Hospice \& Palliative Care 20(1) (2003):23-33.

Pesut, B., Sinclair, S. \& Fitchett, G., "Health Care Chaplaincy: A Scoping Review of the Evidence 20092014," J Health Care Chaplain 22(2) (2016):67-84. doi:10.1080/08854726.2015.1133185

Peterman, Amy H., et al., "Measuring Spiritual Well-Being in People with Cancer: The Functional Assessment of Chronic Illness Therapy-Spiritual Well-Being Scale (FACIT-Sp)," Annals of Behavioral Medicine 24(1), (2002):49-58.

Puchalski, C., Ferrell, B. \& Virani, R., "Improving the Quality of Spiritual Care as a Dimension of Palliative 
Care the Report of the Consensus Conference," Journal of Palliative Medicine. 12(10) (2009):885-904.

Puchalski, Christina, "Improving the Quality of Spiritual Care as a Dimension of Palliative Care: The Report of the Consensus Conference," Journal of Palliative Medicine 12(10) (2009):885-904.

Razman, M. R. \& Hamjah, S. H., "Dakwah dalam Dimensi Kerohanian Penjagaan Paliatif Menurut Pendekatan Badi' al-Zaman Sa'id al-Nursi," Jurnal Al-Hikmah. 7(1) (2015):33-47.

Rome, Robin B., Luminais, Hillary H., Bourgeois, Deborah A. \& Blais, Christopher M., "The Role of Palliative Care at the End of Life," The Ochsner Journal 11 (2011):348352.

Al-Qārì. "Kitāb Janā'iz Bāb 'Iyādah al-Marị̣ wa Thawāb al-Marị̣." Dalam Sharah Mishkāt al-Mașābīh 4, ed. S. J. `Aythani. Beirut: Dār al-Kutub al-`Ilmiyyah, 2002.

Sa'ari, C. Z. \& Syed Muhsin, S. B., "Cadangan Model Psikoterapi Remaja Islam Berasaskan Konsep Tazkiyah al-Nafs," Jurnal Usuluddin 36 (2012):49-74.

Sa'id Hawa. Ulasan al-Hikam (Kata-kata Hikmah Syeikh ibn Ata'illah Al-Sakandari. Johor: Perniagaan Jahabersa, 2002.

Schulz, C., Schlieper, D. \& Altreuther, C. "The Characteristics of Patients Who Discontinue Their Dying Process - An Observational Study at a Single University Hospital Centre," BMC Palliat Care 14 (2015):72. doi:10.1186/s12904-015-0070-7

Al-Shahri, M. Z. \& Al-Khenaizan, A., "Palliative Care for Muslim Patients," The Journal of Supportive Oncology 3(6) (2005): 432-436.

Al-Shahri, M. Z., "Culturally Sensitive Caring for Saudi Patients," Journal of Transcultural Nursing 13(2) (2002):133-138.

Sholeh, M. Terapi Solat Tahajud: Menyembuhkan Berbagai Penyakit. Jakarta: Noura Books, 2012. 
Sumner, C. H., "Recognizing and Responding," The American Journal of Nursing 98(1) (1998):26-31.

Syed Muhsin, S. B. \& Sa'ari, C. Z., "Beberapa Aspek Psikoterapi Islam dalam Kitab Jawi, 'Penawar Bagi Hati' oleh Sheikh Abdul Qadir Al-Mandili," Jurnal Afkar 14 (2013):109-142.

Taheri, N., "Health Care in Islamic History and Experience," EthnoMed, 2008. Diakses 12 Nov 2014, http://ethnomed.org/cross-cultural-

health/religion/health-care-in-islamic-history-andexperience/

Tami Borneman, B. F. a. C. M. P., "Evaluation of the FICA Tool for Spiritual Assessment," Journal of Pain and Symptom Management 40(2) (2010):163-173. doi:10.1016/j.jpainsymman.2009.12.019

Thomas, M., Irwin, S. A. \& Meier, E. A., "Enhancing Legacy in Palliative Care: Study Protocol for a Randomized Controlled Trial of Dignity Therapy Focused on Positive Outcomes," Bmc Palliative Care 14(44) (2015):1-8.

Ulwan, A. N. Tarbiyatu 'l-Aulad fi 'l-Islam. (Terj. S. Kamalie \& H. N. Ali). Kuala Lumpur: Victory Agencie, 1996.

Villagomeza, L. R., "Spiritual Distress in Adult Cancer Patients: Towards Conceptual Clarity," Holistic Nursing Practices. 19(6) (2005):285-294.

Virdun, C., Luckett, T. \& Davidson, P. M., "Dying in the Hospital Setting: A Systematic Review of Quantitative Studies Identifying the Elements of End-Of-Life Care That Patients and Their Families Rank as Being Most Important," Palliative Medicine 29(9) (2015):774 -796. Wright, M., "Hospice Care and Models of Spirituality," European Journal of Palliative Care 11(2) (2004):75-78. 